\title{
Enterobius vermicularis larvae in urine sample of female student:The first case report in Indonesia
}

\begin{abstract}
Genital enterobiasis is caused by migration of adult females or larvae of Enterobius vermicularis (E. vermicularis). Adult female E. vermicularis migrate to the genital organs after laying eggs at perianal area. The eggs in the perianal will hatch into larvae and walk into the anus. In female patients, the chance of larval entry into the genital is greater because it is located adjacent to the anal. A larvae of E. vermicularis was found in direct urine of a 19-year-old female student. There were no other signs and symptoms of enterobiasis in her. This ectopic enterobiasis in genital tract was the first report in Indonesia.
\end{abstract}

Keywords: Enterobius vermicularis, genital enterobiasis, direct urine
Volume 9 Issue I - 202 |

\section{Didik Sumanto, Sayono Sayono, Puji Lestari Mudawamah \\ Department of Epidemiology, Faculty of Public Health, \\ Universitas Muhammadiyah Semarang, Indonesia}

\begin{abstract}
Correspondence: Didik Sumanto, Faculty of Public Health, Universitas Muhammadiyah Semarang, Jalan Kedungmundu Raya 18, Semarang, Jawa Tengah, Indonesia (50273),
\end{abstract} Tel +62-822215866 I7, Email didik.24272@gmail.com

Received: January 26, 2021 | Published: February 03, 2021

\section{Introduction}

Genital enterobiasis is a case of ectopic enterobiasis found in several countries, though the prevalence of the disease is very low. Some reported-cases were found accidentally when patients were observed in diagnostic process of the other diseases. A number of ectopic enterobiasis were detected in papsmear diagnosis such as an endometrial enterobiasis in a 40-years-old Chinese woman, ${ }^{1}$ cervical carcinoma with enterobiasis in 35-years-old ${ }^{2}$ and vaginal enterobiasis in 40-years-old Indian women, ${ }^{3}$ existance of E. vermicularis ova in vaginal smear in 37 -years-old Korean women, ${ }^{4}$ and a fallopian tube enterobiasis in a 23-years-old of pregnant Malaysian woman. ${ }^{5}$ A number of $E$. vermicularis eggs were found in the kidney of a 51-years-old woman French with abdominal pain, ${ }^{6}$ while the adult E.vermicularis were found in the urine of a 7-years-old female in Irak. ${ }^{7}$ A massive infestation of E. vermicularis was found among the nocturnal enuresis of 20 -years-old women in Romania. ${ }^{8}$ These ectopic enterobiasis cases occurred in a broad range of women age indicated that this disease is a general problem of community and necessary to be treated. This case report presents an unexpected result of $E$. vermicularis larvae occurrence in urine sample of a 19-years-old female student who did not appear clinical sign and symptom of the disease.

\section{Case presentation}

Larvae of Enterobius vermicularis were studied from the urine sample of a female student at practicum in biomedical laboratory of Public Health Faculty of Universitas Muhammadiyah Semarang in November 2018. The E. vermicularis larvae were found in urine sample after examination through precipitation method. This method was modified with centrifugation. The larvae were observed through microscopic observations.

The self-collection of direct urine sample was taken by probandus in boarding house about 15 to 30 minutes before go to campus. The probandus were female students who took the course of Biomedical 1. Each female student is required to take direct urine for practicum specimens. A $10 \mathrm{ml}$ urine sample was poured into a centrifuge tube and rotated at $2500 \mathrm{rpm}$ for 10 minutes. The sediment and supernatant of the urine was separated. Two drops of sediment was taken and prepared in the object glass slide to be examined microscopically to finding of adult, larva or egg of E. vermicularis worm with gradual magnification. ${ }^{9}$ We found larvae worm (Figure 1) in the urine sample. There are no other intestinal worms that can migrate to the genital organs..$^{10} E$. vermicularis is the one species may to migrate to the female genital organs due to the anatomical position of the anus and adjacent genital holes. ${ }^{2-4}$ The microscopic images of larvae in this finding indicate the presence of an esophageal bulb. The esophageal bulb is a specific feature of E. vermicularis. ${ }^{11}$ No other morphological features are more specific. The behavior of female worms laying eggs in the perianal, ${ }^{12}$ larvae migration behavior, ${ }^{10}$ and the existence of several reports of cases of genital infection ${ }^{1-8}$ reinforces this suspicion. The hatched larvae will enter into the rectum ${ }^{11}$ or migrate to the genital tract in women. ${ }^{13}$ No other species of intestinal nematode were migration reported in the genital tract. Its means, only this species can migrate to the genital tract. Finally, we concluded that this larvae is E.vermicularis worm.

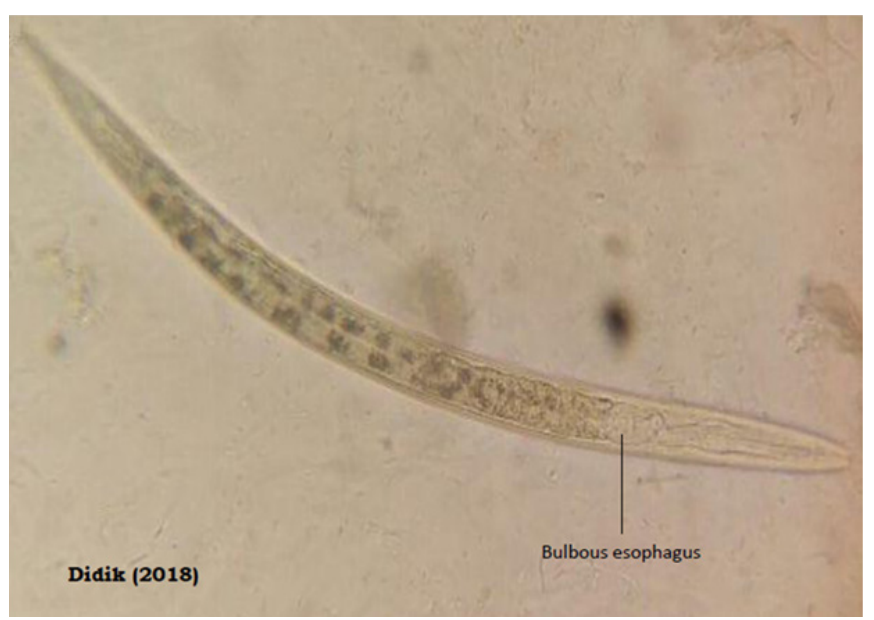

Figure I E. vermicularis larvae from urine specimen.

At first, we suspected that the urine sample was contaminated with fecal or perianal material from the collected bottle, water source, 
bedroom linen or the other sources so that an in-depth interview was done with the probandus. In-deep interview with the students finds valid information about direct urine. Its specimen was not contaminated with fecal or other perianal material during sampling. Probandus went to campus from her house in Jepara, around $70 \mathrm{~km}$ from Semarang city. In the morning, she urinates when taking a bath and cleaned with clean water. When arrived in Semarang, she went to her boarding house to collect her sample urine with the clean bottle that prepared before, and then brought it to laboratory. It means that the urine sample was pure excreted from her urinary tract and was not contaminated with the other material sources such as bathroom water, towel, and bedroom linen. We suspect that there had been migration of larvae from the perianal area after hatching a few hours before collected urine specimens.

\section{Conclusion}

The existence of E.vermicularis larvae in the urine sample indicated that the probandus was infected with the worm. Unfortunately, the other data such as sample from perianal swab or fecal materials are cannot obtained so could not strengthen this finding. We found many studies were reported the occurrence of $E$. vermicularis infection from fecal and perianal material samples. ${ }^{14-22}$ Enterobiasis cases were never reported based on laboratory diagnosis from the urine specimen. This finding is the first report of genital enterobiasis in Indonesia. Prevalence, transmission mechanisms and determinant factors of the ectopic enterobiasis in genital tract among women in Indonesia are not clearly understood so that the further studies are necessary to be done followed by the prompt public health action to control this disease.

\section{Acknowledgments}

Thanks to Probandus for allowing this case report to publication.

\section{Conflicts of interest}

Authors declare that there is no conflict of interest.

\section{References}

1. Ying WN, Bian N. Enterobius Vermicularis Infestation of the Endometrium-A Cause of Menstrual Irregularity and Review of Literature. Ann Acad Med. 2011;40(11):514-515.

2. Raju K, Verappa S, Murthy S. Enterobius vermicularis infestation masquerading as cervical carcinoma : A cytological diagnosis. $J$ Nat Sci Biol Med. 2015;6(2):476-479.

3. Shetty J, Kulkarni D, Prabhu V. Eggs containing larvae of Enterobius vermicularis in vaginal smear. $J$ Cytol. 2012;29(1):94-96.

4. Kim SCE, Lee YHH, Ko WLS, et al. Enterobius vermicularis Ova in a Vaginal Smear. Korean J Pathol. 2010;44:341-342.

5. Ngui R, Ravindran S, Lan B, et al. Enterobius vermicularis Salpingitis Seen in the Setting of Ectopic Pregnancy in a Malaysian Patient. J Clin Microbiol. 2014;52(9):3468-3470.
6. Cateau E, Yacoub M, Tavilien C. Enterobius vermicularis in the kidney : an unusual location. J Med Microbiol. 2010;59(7):860-861.

7. Al-Saeed WM, Saeed NH. Isolation of Enterobius Vermicularis from Urine of Urinary Tract Infected Girl : A Case Report and Review of Literatures. Int J Enhanc Res Sci Technol Eng. 2015;4(5):169-171.

8. Costache C, Jalali-zadeh B. Enterobius vermicularis (PINWORMS) infection and enuresis (bedwetting) case report. Sci Parasitol. 2009;10(12):79-81.

9. Sumanto D, Ghofur A. Pemeriksaan Spesimen Urine Untuk Deteksi Genital Enterobiasis. In: Teknik Identifikasi Dan Pemeriksaan Laboratorium Infeksi Kecacingan. Ikatan Analis Kesehatan Indonesia Semarang; 2016. 67-69 p.

10. Kandun IN. Enterobiasis. In: Manual Pemberantasan Penyakit Menular (Eds. J Chin). 17th ed. Berkeley, USA; 2000. 194-195 p.

11. CDC. Enterobiasis. DPDx-Laboratory Identification of Parasites of Public Health Concern; 2019.

12. McCarthy J, Moore T. Enterobiasis. In: Tropical Infectious Diseases: Principles, Pathogens, \& Practice. 2nd ed. Elsevier B.V.; 2006. 1248$1251 \mathrm{p}$.

13. Diemert DJ. Intestinal Nematode Infections. In: Goldman's Cecil Medicine (Twenty Fourth Edition). 24th ed. Elsevier B.V.; 2012. 2064 $2068 \mathrm{p}$.

14. Yusuf Y. Infeksi Cacing Kremi Pada Penderita HIV Positif di Makassar. $J$ Bionature. 2015;16(1):54-57.

15. Hermawan N. Uji Paparan Telur Cacing Kremi Pada Apusan Perianal dan Sprei Tempat Tidur Anak; 2011.

16. Perdana AS, Keman S. Correlation between Hands and Nails Hygiene with Enterobiasis Incidence on Student in Elementary School of Kenjeran No. 248 Bulak, Surabaya. Jurnal Kesehatan Lingkungan. 2013;7(1):7-13.

17. Chai J, Yang SK, Kim JW, et al. High Prevalence of Enterobius vermicularis Infection among Schoolchildren in Three Townships around Yangon, Myanmar. Korean J Parasitol. 2015;53(6):771-775.

18. Ali S, Amiri N, Rahimi MT, et al. Prevalence of Enterobius vermicularis infection among preschool children, Babol, North of Iran. J Parasit Dis. 2016;40(4):1558-1562.

19. Afrakhteh N, Marhaba Z, Ali S, et al. Prevalence of Enterobius vermicularis amongst kindergartens and preschool children in Mazandaran Province, North of Iran. J Parasit Dis. 2016;40(4):1332-1336.

20. Wang S, Yao Z, Hou Y, et al. Prevalence of Enterobius vermicularis among preschool children in 2003 and 2013 in Xinxiang city, Henan province, Central China. Parasite. 2016;23(30):1-5.

21. Tara D, Maharjan M. Pinworm (Enterobius vermicularis) Infection in Children of Barbhanjyang VDC, Tanahun District, Nepal. J Inst Sci Technol. 2015;20(2):18-21.

22. Lutfiana F. Hubungan Perilaku Higiene dan Sanitasi Lingkungan Rumah Dengan Kejadian Infeksi Enterobius vermicularis Di Desa Rimbulor Rejosari Karangawen Demak; 2010. 